\title{
Estimation of Growth Rate and Instability Analysis of Area, Production and Yield of Rice in Odisha State of India
}

\author{
Nitiprasad Namdeorao Jambhulkar*, Sushree Sangeeta Jena, \\ Biswajit Mondal and Parshuram Samal \\ ICAR-National Rice Research Institute, Cuttack - 753006, India \\ *Corresponding author
}

\section{Ke ywords \\ Rice, Odisha, area, Production, Yield, Growth rate, Instability}

Article Info

Accepted:

22 June 2020

Available Online:

10 July 2020

\section{A B S T R A C T}

Agricultural growth with stability has been a matter of concern in Odisha. As rice is the major crop growing in the state, the present study was therefore carried out with the objectives to work out the district wise growth rate of area, production and yield of rice and to estimate district wise instability in area, production and yield of rice in districts of Odisha. The study was based on the secondary data on area, production and yield of rice in Odisha state collected from different sources like Directorate of Agriculture and Farmers Welfare, Directorate of Economics and Statistics, Department of Agriculture \& Farmers' Empowerment, Government of Odisha and other departments. The data under study for all district of Odisha from 1993-94 to 2016-17 was split into four periods i.e. period I: 199394 to1999-2000, period II: 2001-02 to 2009-10, period III: 2011-2012 to 2016-17 and period IV: 1993-94 to 2016-17. The growth rates for area, production and yield were computed using exponential model. The instability in area, production and productivity was measured through Cuddy Della Valle's instability index was used to analyze the instability in area, production and yield of districts of Odisha. The compound growth rate for production was significant and highest for Deogarh district during period III. Compound growth rate for area for all the periods including overall period, shows a negative growth rate. But growth rate in case of area was highest during period I in Puri district. Lowest growth rate in area during period I was found in Ganjam district. The compound growth rate for production and yield showed positive growth rate in the entire periods except for period I. The highest Cuddy Della Valle's instability index for area was observed in Ganjam during period I. The highest instability index for production and productivity was observed Bolangir district during period III. The instability in case of area, production and yield was highest during the period III. The growth in area was negative during all the four periods and the growth in production is mainly due to growth in yield.

\section{Introduction}

India is a developing country where agriculture even at the present time is very important as it provides livelihood for the more than fifty percent of total work force and supplies food to the entire country. Agriculture has been and will continue to be 
the lifeline of the Indian economy. The contribution of agricultural sector to the GDP has continued to decline over the years than that of other sectors. As largest private enterprise in India, agriculture contributes nearly about $17-18$ per cent of the national GDP in 2018.

There are many factors, which affect the growth of agricultural output. Some of these are, area and yield are the major ones (Singh, 1981; Cauvery, 1991). These sources of output growth have relevance in deciding programs of agricultural development and priorities of investment in it (Ranade, 1980; Deosthali and Chandrahekhar, 2004). Thus, it becomes vital to find the cause of growth rates differ from one another, so that the bottlenecks could be removed to achieve the fast development of agricultural sector (Sikka and Vaidya, 1985). Many research workers have worked on growth rate of rice in different regions (Ayyasamy and Subramanian, 1979). Instability in rice production is vital for farmers of Odisha. It affects farmers' income, their long term investment, ability to harness next crop and to take risk in new technology. Instability in agricultural production was studied by many researchers in the past (Sen, 1967; Tripathy and Srinivasagouda, 1995; Singh and Swarup, 1998; Bera et al., 2011; Swain, 2012; Susella and Chandrasekaren, 2016).

Rice is the staple food of the Indian diet, and therefore its production and production growth are in the center of food security in India. The production of this crop was insufficient and stagnant before the green revolution in the mid-1960s. During the same period the size of population was increasing very rapidly which results in decrease in food availability per person. However after introduction of green revolution the production of this crop increased considerably. The production of rice in India has increased from 37.61 MT in 1967-68 to 93.34 MT in 2001-02 and to 104.32 MT in 2015-16.

Agriculture is the lifeline of state's economy of Odisha as it provides employment to about $62 \%$ of total workers of the state. Agriculture in Odisha to a considerable extent means growing rice. In Odisha, rice is the staple food of majority of the peoples. Rice crop is grown in large scale in Odisha state. Odisha ranks $4^{\text {th }}$ position in rice production with the production of 8.32 million tonnes with contribution of $8 \%$ of total rice production in India in 2016-17.

Although Odisha has made significant strides in agricultural production, yet the progress has not been uniform in all the districts of the state. It is in this context, the study of trends in area, production and productivity of rice in the state as well as important districts becomes relevant. The instability in rice area, production and yield was noticed due to various factors. While there is an obvious need of agriculture sector's growth, the increased instability in production creates more uncertainty about sustainability of agricultural growth in Odisha. The analysis of crop production is not only important for planning future production, growth strategy of the state but also for financial position. So to analyze the above factors the study has been under taken with the objectives to study the growth rates in area, production and productivity of rice crop in Odisha and to study instability in rates in area, production and productivity of rice crop in Odisha.

\section{Materials and Methods}

The present study is based on secondary data on area, production and yield of rice in Odisha of all the 30 districts of Odisha for the period 1993-94 to 2016-17. The data was collected from Directorate of Agriculture and 
Farmers Welfare, Directorate of Economics and Statistics, Department of Agriculture \& Farmers' Empowerment, Govt. of Odisha and other departments during different time periods. The entire study period was divided into three periods to evaluate the performance of agriculture commodities and to assess the change in relative contribution of different factors to the output growth over the time period. The periods are: Period I - 1993-94 to 1999-2000, Period II - 2001-02 to 2009-10, Period III - 2011-2012 to 2016-17 and Overall period -1993-94 to 2016-17.

\section{Analytical techniques used for analyzing the data}

The present study is based on secondary time series data of rice crop for different districts of Odisha.The analysis was done on the following aspects. The compound growth rates of area, production and yield for rice was computed for three sub periods. The Period I was1993-94 to 1999-2000, Period II was 2001-02 to 2009-10 and Period III was 2011-2012 to 2016-17. The overall period was 1993-94 to 2016-17.

\section{Growth rate analysis}

In the present study, compound growth rate of area, production and yield for rice for each periods were estimated to study the growth in area, production and yield of rice.

The district-wise compound growth rates were estimated with the help of following exponential model.

$\mathrm{Y}=a b^{\mathrm{t}}$

$\log Y=\log a+t \log b$

where, $\mathrm{Y}$ is the time series data of district wise production, area and yield of rice, $t$ is the time term and a is the constant coefficient. The slope coefficient $b$ measures the relative change in $\mathrm{Y}$ for a given absolute change in the value of explanatory variable $t$. If the relative change in $\mathrm{Y}$ is multiplied by 100 , one can get the percentage change or growth rate in $Y$ for an absolute change in time variable t. The slope coefficient $b$ measures the instantaneous rate of growth. The compound growth rate $r$ can be calculated as follows:

$\operatorname{CGR}(r)=[$ Antilog $(\log b)-1] \times 100$

The above equation has estimated by using OLS method. The t-test was used to test the significance of $b$. Above equation is generally used on considering that the changes in agricultural output in a given year would depend upon the output in preceding year. (Minhas, 1966; Singh and Rai, 1997; Deosthali and Chandrashekhar, 2004; Prabakaran and Sivapragasam, 2013; Singh et al., 2014; Tewari et al., 2017). Since, the performance of agriculture has been affected by widespread drought and climatic factors, the growth rate of area, production and yield has been calculated using three years average data to smoothen the values.

\section{Instability analysis}

To measure the instability of area, production and productivity, Cuddy-Della Valle index is used. Cuddy Della Valle Instability index (Cuddy and Della Valle, 1978) is a modification of coefficient of variation to accommodate trend present in the data, which is commonly present in economic time series data. Therefore, to examine the extent of risk involved in crop production, the instability in the crops' area and production in the state was estimated using Cuddy-Della Valle Index as:

$$
\operatorname{CDVI}=\mathrm{CV}^{\sqrt{\left(1-R^{2}\right)}}
$$

where CDVI = Cuddy-Della Valle Instability index (per cent); 
$\mathrm{CV}=$ Coefficient of variation (per cent);

Adj $\mathrm{R}^{2}=$ Coefficient of determination from a time trend regression adjusted by the number of degree of freedom (adjusted $R^{2}$ ). It is the adjusted coefficient of determination.

\section{Results and Discussion}

\section{Growth rate analysis}

The district wise compound growth rate in area, production and yield of rice in Odisha were computed for four periods as mentioned above. The growth performance for area, production and yield for four periods has been presented in Table 1. During the period most of the districts of Odisha recorded negative growth rate of area, production and yield of rice. Table 1 shows that, during the period I (1993-94 to 1999-2000), growth rate of area, production and yield recorded mostly negative for rice. For area, Puri district recorded the highest growth rate $2.48 \%$ per annum followed by Sundargarh at the rate of $0.94 \%$ per annum. The annual growth rate of production was highest for Sambalpur at the rate of $2.54 \%$ per annum followed by Rayagada district at the rate of $1.54 \%$ per annum. Ganjam district shows the highest growth rate of $4.26 \%$ per annum in yield followed by Sambalpur at the rate of $1.61 \%$ per annum. It had been found that for Odisha, the growth rate of area, production and yield was $-1.4 \%,-3.55 \%$ and $-2.18 \%$ per annum respectively and growth rate for production was significant at $1 \%$.

From the study of period II (2000-01 to 2009$10)$, the growth rate of production and yield was positive for all the districts. For area, Sonepur district recorded highest growth rate $1.83 \%$ followed by Kalahandi district $1.31 \%$ per annum. Growth rate of Nuapada district was highest for both production $(9.19 \%$ per annum) and yield (8.93\% per annum) followed by Bolangir district with the growth rate of $8.93 \%$ and $8.72 \%$ per annum for production and yield respectively. In this period, growth rate in Odisha was positive for both production $(4.33 \%$ per annum) and yield ( $4.41 \%$ per annum) but negative for area ($0.08 \%$ per annum). So in comparison to period I, period II had positive growth rate where production and yield were found to be significant at $1 \%$.

In period III (2010-11 to 2016-17), growth rate of all the districts was positive for yield whereas negative for area for most of the districts. Deogarh district shows highest growth rate $2.28 \%$ per annum for area followed by $1.95 \%$ per annum for Sambalpur district. Deoghar district (16.47\% per annum) recorded highest growth rate for production followed by Angul district $(13.06 \%$ per annum); whereas Angul district (15.42\% per annum) recorded highest growth rate for yield followed by Deoghar district (13.88\% per annum). The growth rate of Odisha for area, production and yield was $-1.07 \%, 2.31 \%$ and $3.41 \%$ per annum respectively.

During period IV (1993-94 to 2016-17), growth rate for production and productivity was positive for most of the districts. For area, Boudha recorded highest growth rate $2.48 \%$ per annum followed by Rayagada district (1.6\% per annum). Highest growth rate for production and yield was $4.1 \%$ and $3.27 \%$ per annum respectively recorded by Sonepur district followed by $3.83 \%$ and $2.7 \%$ per annum for production and yield respectively for Kalahandi district. For this period of 24 years, growth rate of Odisha for area, production and yield for Odisha was $0.03 \%, 2.0 \%$ and $2.03 \%$ per annum respectively. Highest growth rate for area i.e. $2.48 \%$ was found in Puri district during Period I and in Boudha district during Period IV. It was $16.47 \%$ per annum for production in Deoghra district and $15.42 \%$ per annum for yield in Angul district during Period III. 


\section{Instability index of rice}

One should not be obvious of instability by taking only the growth rates. The growth rates will explain only the rate of growth over the period, whereas, instability would judge, whether the growth performance was stable or unstable for the period for the variable under study. In order to know the instability in area, production and yield of rice, the fluctuation was measured by Cuddy-Della Valle Index of instability. The results are presented in Table 2 and discussed as under for the period with year division of three periods and overall period also. Fluctuation in area, production and productivity due to the uncontrollable factors like climatic conditions can cause variation.

In period I, highest instability for area $(109.9 \%)$ and yield $(51.86 \%)$ has been found in Ganjam district while Nayagarh recorded highest instability in production. Least instability for area, production and yield recorded in Mayurbhanj (1.91\%), Nawarangpur (11.87\%) and Koraput $(8.02 \%)$ respectively. The instability varies from 1.91 to $109.98 \%$ per annum for area, 11.87 to $42.14 \%$ per annum for production and 8.02 to $51.86 \%$ per annum for yield. The instability of Odisha for area, production and yield was found to be $10.53 \%, 11.49 \%$ and $14.29 \%$ per annum respectively.

During the II period of study, Puri showed highest instability in area $(10.71 \%)$ while highest instability for both production and yield i.e. $48.18 \%$ and $46.43 \%$ per annum respectively has been recorded by Jharsaguda district. The lowest instability in this period for area was found in Bargarh district, i.e. $2.52 \%$ per annum. Lowest instability in production and yield was recorded for Bargarh (14.42\%) and Bhadrak (12.71\%) district respectively. The instability varies from $2.52 \%$ to $10.71 \%$ per annum for area,
$14.42 \%$ to $48.18 \%$ per annum for production and $12.71 \%$ to $46.43 \%$ per annum for yield. In Odisha, the instability of area, production and yield were $1.69 \%, 18.74 \%$ and $17.67 \%$ per annum respectively.

During the study period III, highest instability for area was $88.58 \%$ found in Sonepur district. Bolangir district recorded highest instability in production and yield i.e. 58.77\% and $65.25 \%$ per annum respectively. The lowest instability for production was found in Jagatsinghpur, i.e. $15.68 \%$ per annum. Least instability for area and yield was recorded in Balasore (35.39\%) and Puri (23.23\%) districts respectively. In this period, instability for area varies from $35.39 \%$ to $88.58 \%$ per annum, for production varies from $15.68 \%$ to $58.77 \%$ per annum and for yield varies from $23.23 \%$ to $65.25 \%$ per annum. In Odisha, instability in area, production and yield was $2.94 \%$, $14.45 \%$ and $13.46 \%$ per annum respectively.

In period IV, Ganjam district showed highest instability in area, i.e. $84.19 \%$ per annum. Highest instability for production and yield was $48.11 \%$ and $50.56 \%$ per annum recorded by Bolangir district. Lowest instability for area was $18.73 \%$ found Balasore district, while least instability for production and productivity was $17.79 \%$ and $19.39 \%$ per annum respectively found in Bargagh district. Instability for area varies from $18.73 \%$ to $84.19 \%$, for production varies from $17.79 \%$ to $48.11 \%$ and for yield varied from $19.39 \%$ to $50.56 \%$ per annum. In Odisha, instability for area, production and yield was observed to be $6.03 \%, 16.30 \%$ and $15.62 \%$ per annum respectively.

Overall instability for area was highest in Ganjam district, i.e. $109.98 \%$ and lowest in Mayurbhanj district, i.e. $1.91 \%$ per annum during period I. 
Table.1 District wise Growth Rate of Rice in Odisha for different periods

\begin{tabular}{|c|c|c|c|c|c|c|c|c|c|c|c|c|c|}
\hline \multirow[t]{2}{*}{ S. N. } & \multirow[t]{2}{*}{ Districts } & \multicolumn{3}{|c|}{$\begin{array}{c}\text { Period I } \\
(1993-94 \text { to 1999-2000) }\end{array}$} & \multicolumn{3}{|c|}{\begin{tabular}{|l} 
Period II \\
(2000-01 to 2009-10)
\end{tabular}} & \multicolumn{3}{|c|}{\begin{tabular}{|l} 
Period III \\
(2010-11 to 2016-17)
\end{tabular}} & \multicolumn{3}{|c|}{$\begin{array}{l}\text { Period IV } \\
\text { (1993-94 to 2016-17) }\end{array}$} \\
\hline & & $\mathbf{A}$ & $\mathbf{P}$ & $\mathbf{Y}$ & $\mathbf{A}$ & $\mathbf{P}$ & $\mathbf{Y}$ & $\mathbf{A}$ & $\mathbf{P}$ & $\mathbf{Y}$ & $\mathbf{A}$ & $\mathbf{P}$ & $\mathbf{Y}$ \\
\hline 1 & Angul & $-0.68 * *$ & -4.65 & -4 & -0.49 & 2.86 & 3.37 & -2.04 & $13.06 * *$ & $15.42 * *$ & -0.47 & 0.20 & 0.67 \\
\hline 2 & Balasore & $-0.54 *$ & $-5.12 *$ & $-4.60 *$ & 0.05 & $2.44 * *$ & $2.39 * *$ & -1.61 & 1.29 & 2.94 & 0.10 & $1.40^{*}$ & $1.31 *$ \\
\hline 3 & Bargarh & -1.04 & -2.55 & -1.53 & 0.01 & $3.19^{*}$ & $3.18 *$ & -0.13 & 1.96 & 2.10 & $0.81 * *$ & $1.88^{*}$ & 1.05 \\
\hline 4 & Bhadrak & -0.56 & $-2.37 * *$ & -1.82 & 0.38 & $4.92 *$ & $4.52 *$ & -0.77 & 1.26 & 2.05 & 0.59 & $1.13^{*}$ & 0.53 \\
\hline 5 & Bolangir & 0.01 & -6.14 & -6.15 & 0.32 & $9.08 *$ & $8.72 *$ & -0.88 & 8.55 & 9.51 & $0.97 *$ & $3.50 *$ & $2.51 *$ \\
\hline 6 & Boudha & 0.56 & -0.63 & -1.18 & 0.26 & $7.53^{*}$ & $7.26^{*}$ & -1.57 & 4.80 & 6.47 & $2.48 * *$ & $2.74 *$ & 0.26 \\
\hline 7 & Cuttack & 0.22 & $-4.80 * *$ & $-5^{*}$ & $-0.96 *$ & $3.84 *$ & $4.85^{*}$ & -2.37 & 2.12 & 4.61 & 0.54 & $1.09 * *$ & 0.55 \\
\hline 8 & Deoghar & -0.49 & $-5.44 * *$ & $-4.98 * *$ & -0.50 & $5.11 * *$ & $5.63^{*}$ & 2.28 & $16.47 * *$ & $13.88 * *$ & -0.03 & $2.22 * *$ & 2.25 \\
\hline 9 & Dhenkanal & -0.08 & $-3.73^{*}$ & $-3.66 * *$ & $-0.99 *$ & $6.05^{*}$ & $7.12 *$ & -2.43 & $8 * *$ & 10.68 & -0.47 & $1.55^{*}$ & $2.03 *$ \\
\hline 10 & Gajapati & $0.90 * *$ & -3.21 & -4.07 & -0.19 & -1.01 & -0.82 & 1.23 & -0.39 & -1.60 & 1.05 & $-0.91 *$ & $-1.94 *$ \\
\hline 11 & Ganjam & -12.84 & $-9.12 *$ & 4.26 & -0.25 & $5.18^{*}$ & $5.44^{*}$ & -1.59 & 4.14 & 5.83 & 1.45 & -0.17 & -1.60 \\
\hline 12 & Jagatsingpur & -0.25 & $-4.97 * *$ & $-4.73 *$ & $-1.08 *$ & $5.09 *$ & $6.24 *$ & -0.58 & $4.16^{*}$ & 4.76 & -0.28 & $1.68^{*}$ & $1.96^{*}$ \\
\hline 13 & Jajpur & 0.27 & $-4.88 *$ & $-5.13 *$ & -0.37 & $6.39 *$ & $6.79 *$ & -2.22 & -0.22 & 2.04 & -0.19 & 0.36 & 0.55 \\
\hline 14 & Jharsuguda & -0.02 & -4.21 & -4.19 & -0.85 & $5.49 * *$ & $6.40 *$ & 1.49 & 11.13 & $9.50 * *$ & 1.15 & -0.85 & -1.97 \\
\hline 15 & Kalahandi & $0.68 * *$ & -0.57 & -1.24 & $1.31 *$ & $2.98 * *$ & 1.64 & -3.23 & 0.52 & 3.87 & $1.10 *$ & $3.83^{*}$ & $2.70 *$ \\
\hline 16 & Kandhamal & -0.22 & 0.69 & 0.91 & 0.02 & $2.49 * *$ & $2.47 *$ & -3.99 & -0.39 & 3.75 & -1.97 & -0.17 & 1.83 \\
\hline 17 & Kendrapara & -0.14 & $-8.48 *$ & $-8.35^{*}$ & -0.02 & $5.32 *$ & $5.34 *$ & -1.97 & 1.08 & 3.11 & -0.12 & 0.38 & 0.50 \\
\hline 18 & Keonjhar & -0.20 & $-3.34 *$ & $-3.15 * *$ & $-0.55^{* *}$ & $5.65^{*}$ & $6.24 *$ & -0.76 & $5.72 *$ & 6.53 & -0.24 & $1.48 *$ & $1.72 *$ \\
\hline 19 & Khurda & -0.73 & $-4.38 * *$ & $-3.67 * *$ & $-0.94 * *$ & 2.78 & $3.75 * *$ & -1.70 & 0.06 & 1.79 & -0.02 & 0.01 & 0.03 \\
\hline 20 & Koraput & $-1.03 *$ & -0.17 & 0.87 & $-0.95 * *$ & 1.47 & $2.44 *$ & 0.50 & $7.31 *$ & 6.78 & $1.54 * *$ & $2.19 *$ & $0.64 *$ \\
\hline 21 & Malkangiri & $-1.90 * *$ & $-4.86 * *$ & $-3.02 * *$ & 0.03 & $4.81 *$ & $4.78 * *$ & 0.88 & 4.68 & 3.76 & $1.28 *$ & $2.16^{*}$ & 0.86 \\
\hline 22 & Mayurbhanj & 0.45 & $-3.52 * *$ & $-3.95 * *$ & -0.16 & $4.13^{*}$ & $4.30 *$ & 0.11 & $5.06 *$ & 4.95 & 0.43 & $1.22 *$ & $0.78 *$ \\
\hline 23 & Nawarangpur & 0.25 & 1.08 & 0.83 & 0.22 & 1.63 & 1.41 & -1.04 & $7.91 * *$ & 9.05 & $0.81 * *$ & $1.94 *$ & 1.12 \\
\hline 24 & Nayagarh & 0.69 & $-6.59 * *$ & $-7.23 * *$ & $-0.36^{* *}$ & $3.97 *$ & $4.34 *$ & -0.43 & 1.11 & 1.55 & 1.04 & -0.59 & $-1.61 * *$ \\
\hline 25 & Nuapada & 0.69 & -0.86 & -1.54 & 0.23 & $9.19 *$ & $8.93 *$ & -1.39 & 1.45 & 2.88 & $1.46^{* *}$ & $3.45^{*}$ & $1.96 *$ \\
\hline 26 & Puri & $2.48^{*}$ & $-5.18 * *$ & $-7.47 *$ & 0.88 & $4 *$ & $3.09^{*}$ & -3.43 & 2.18 & 5.81 & -0.13 & 0.81 & 0.95 \\
\hline 27 & Rayagada & $0.73 * *$ & 1.41 & 0.68 & -0.06 & $3.54 * *$ & $3.60 *$ & -0.92 & 4.20 & 5.17 & $1.60 * *$ & $2.17 *$ & $0.57 * *$ \\
\hline 28 & Sambalpur & $0.91 * *$ & $2.54 * *$ & 1.61 & 0.30 & $5.85^{*}$ & $5.53^{*}$ & 1.95 & 5.43 & 3.42 & $0.44^{*}$ & $1.85^{*}$ & 1.40 \\
\hline 29 & Sonepur & -0.16 & -0.36 & -0.20 & $1.83^{*}$ & $6.13 *$ & $4.22 *$ & 0.55 & $6.76^{* *}$ & 6.18 & $0.80 *$ & $4.10^{*}$ & $3.27 *$ \\
\hline \multirow[t]{2}{*}{30} & Sundargarh & $0.94 *$ & -0.26 & -1.19 & $-1.04 *$ & $6.24 *$ & $7.36^{*}$ & -0.75 & $12.92 * *$ & $13.78 *$ & 0.63 & $2.80^{*}$ & $2.15^{*}$ \\
\hline & Odisha & -1.40 & $-3.55^{*}$ & -2.18 & -0.08 & $4.33^{*}$ & $4.41 *$ & $-1.07 * *$ & $2.31 * *$ & $3.41 *$ & $-0.03 *$ & $0.20^{*}$ & $2.03 *$ \\
\hline
\end{tabular}

$*$ and $* *$ indicate significance level of values at $\mathrm{P}=0.01$ and 0.05 , respectively

A: Area, P: Production; Y: Yield 
Table.2 District wise instability analysis of rice in Odisha for different periods

\begin{tabular}{|c|c|c|c|c|c|c|c|c|c|c|c|c|c|}
\hline \multirow[t]{2}{*}{ S. N. } & \multirow[t]{2}{*}{ Districts } & \multicolumn{3}{|c|}{$\begin{array}{c}\text { Period I } \\
(1993-94 \text { to } 1999-2000)\end{array}$} & \multicolumn{3}{|c|}{$\begin{array}{c}\text { Period II } \\
(2000-01 \text { to } 2009-10) \\
\end{array}$} & \multicolumn{3}{|c|}{$\begin{array}{r}\text { Period III } \\
(2010-11 \text { to } 2016-17) \\
\end{array}$} & \multicolumn{3}{|c|}{$\begin{array}{c}\text { Period IV } \\
(1993-94 \text { to 2016-17) }\end{array}$} \\
\hline & & $\mathbf{A}$ & $\mathbf{P}$ & $\mathbf{Y}$ & $\mathbf{A}$ & $\mathbf{P}$ & $\mathbf{Y}$ & $\mathbf{A}$ & $\mathbf{P}$ & $\mathbf{Y}$ & $\mathbf{A}$ & $\mathbf{P}$ & $\mathbf{Y}$ \\
\hline 1 & Angul & 4.02 & 30.98 & 28.61 & 4.86 & 44.15 & 41.86 & 66.40 & 50.11 & 50.01 & 31.97 & 41.40 & 44.41 \\
\hline 2 & Balasore & 2.78 & 20.58 & 20.97 & 3.31 & 17.61 & 16.18 & 35.39 & 26.30 & 36.22 & 18.73 & 22.26 & 26.96 \\
\hline 3 & Bargarh & 5.83 & 14.94 & 12.72 & 2.52 & 14.42 & 13.46 & 63.36 & 19.39 & 28.58 & 38.30 & 17.79 & 19.39 \\
\hline 4 & Bhadrak & 3.33 & 22.83 & 23.19 & 4.93 & 14.51 & 12.71 & 66.26 & 24.49 & 37.47 & 38.10 & 21.50 & 28.07 \\
\hline 5 & Bolangir & 3.04 & 39.48 & 38.21 & 3.65 & 32.98 & 33.72 & 87.89 & 58.77 & 65.25 & 52.68 & 48.11 & 50.56 \\
\hline 6 & Boudha & 7.67 & 34.74 & 29.46 & 4.43 & 30.62 & 28.73 & 81.63 & 42.56 & 45.64 & 49.68 & 35.38 & 38.92 \\
\hline 7 & Cuttack & 5.67 & 25.54 & 23.92 & 4.80 & 21.85 & 22.07 & 84.13 & 28.48 & 34.84 & 46.55 & 25.68 & 30.58 \\
\hline 8 & Deoghar & 4.32 & 23.67 & 22.55 & 7.71 & 36.81 & 32.45 & 74.07 & 57.02 & 56.94 & 42.59 & 45.82 & 43.59 \\
\hline 9 & Dhenkanal & 4.80 & 20.35 & 22.14 & 3.31 & 35.87 & 33.46 & 72.69 & 33.76 & 41.13 & 35.64 & 31.06 & 36.75 \\
\hline 10 & Gajapati & 5.58 & 18.48 & 17.41 & 8.62 & 25.80 & 19.63 & 53.52 & 47.50 & 50.68 & 31.76 & 29.41 & 27.67 \\
\hline 11 & Ganjam & 109.98 & 28.70 & 51.86 & 5.45 & 28.65 & 25.21 & 57 & 54.87 & 56.61 & 84.19 & 40.56 & 45.50 \\
\hline 12 & Jagatsingpur & 4.68 & 28.59 & 28.09 & 3.65 & 15.03 & 13.65 & 71.70 & 15.68 & 30.02 & 39.55 & 21.94 & 27.25 \\
\hline 13 & Jajpur & 6.03 & 24.43 & 21.25 & 5.58 & 19.58 & 21.18 & 57.42 & 29.92 & 38.44 & 30.46 & 27.16 & 31.74 \\
\hline 14 & Jharsuguda & 3.05 & 28.98 & 29.03 & 5.75 & 48.18 & 46.43 & 60.50 & 43.46 & 31.94 & 31.34 & 40.64 & 39.36 \\
\hline 15 & Kalahandi & 1.98 & 25.85 & 25.20 & 3.83 & 26 & 25.27 & 67.89 & 42.77 & 45.24 & 39.31 & 35.60 & 35.15 \\
\hline 16 & Kandhamal & 8.63 & 19.47 & 12.36 & 5.29 & 23.59 & 19.58 & 54.86 & 36.26 & 36.10 & 27.49 & 24.46 & 23.56 \\
\hline 17 & Kendrapara & 5.85 & 18.38 & 18.27 & 2.99 & 17.86 & 17.77 & 64.50 & 25.45 & 31.74 & 36.63 & 25.68 & 29.62 \\
\hline 18 & Keonjhar & 2.99 & 17.75 & 16.56 & 3.98 & 24.36 & 22.47 & 49.75 & 27.63 & 38.78 & 25.10 & 25.18 & 29.62 \\
\hline 19 & Khurda & 6.36 & 22.69 & 22.53 & 5.92 & 26.78 & 25.70 & 61.67 & 33.98 & 42.64 & 31.65 & 27.06 & 31.39 \\
\hline 20 & Koraput & 6.40 & 13.06 & 8.02 & 5.62 & 18.15 & 14.97 & 48.29 & 21.42 & 31.71 & 27.69 & 18.73 & 22.25 \\
\hline 21 & Malkangiri & 8.47 & 22.03 & 20.06 & 4.95 & 21.91 & 22.70 & 57.74 & 35.16 & 43.37 & 36.49 & 29.19 & 30.46 \\
\hline 22 & Mayurbhanj & 1.91 & 18.93 & 19.39 & 4.35 & 18.77 & 16.51 & 51.83 & 34.21 & 43.62 & 27.37 & 24.98 & 29.05 \\
\hline 23 & Nawarangpur & 2.22 & 11.87 & 10.31 & 4.83 & 23.91 & 23.35 & 69.16 & 41.84 & 50.55 & 39.02 & 31.04 & 36.31 \\
\hline 24 & Nayagarh & 4.99 & 42.14 & 39.71 & 3.72 & 24.21 & 22.97 & 70.04 & 50.68 & 54.29 & 40.37 & 37.34 & 38.65 \\
\hline 25 & Nuapada & 4.77 & 15.61 & 15.20 & 3.05 & 40.82 & 38.49 & 61.88 & 40.13 & 48.17 & 35.38 & 37.64 & 39.06 \\
\hline 26 & Puri & 9.08 & 25.82 & 25.06 & 10.71 & 20.01 & 19.77 & 51.23 & 18.70 & 23.23 & 27.66 & 21.04 & 26.14 \\
\hline 27 & Rayagada & 4.79 & 19.49 & 16.88 & 10.65 & 22.69 & 17.41 & 58.13 & 39.35 & 45.72 & 33.46 & 28.38 & 29.37 \\
\hline 28 & Sambalpur & 3.92 & 17.15 & 15.78 & 4.83 & 28.41 & 26.33 & 63.54 & 36.43 & 35.58 & 39.39 & 28.14 & 26.57 \\
\hline 29 & Sonepur & 3.52 & 12.88 & 12.21 & 4.33 & 15.90 & 15.89 & 88.58 & 25.30 & 29.63 & 61.30 & 25.86 & 24.54 \\
\hline \multirow{2}{*}{30} & Sundargarh & 3.15 & 14.16 & 12.51 & 4.13 & 34.20 & 32.45 & 70.92 & 39.26 & 45.77 & 39.86 & 34.38 & 37.95 \\
\hline & Odisha & 10.53 & 11.49 & 14.29 & 1.69 & 18.74 & 17.67 & 2.94 & 14.45 & 13.46 & 6.03 & 16.30 & 15.62 \\
\hline
\end{tabular}

A: Area, P: Production; Y: Yield 
Similarly, instability in production was highest during period III in Bolangir district, i.e. $58.77 \%$ while lowest in Nawarangpur, i.e. $11.87 \%$ per annum during period I. Instability for yield was highest during period III in Bolangir district, i.e. $65.25 \%$ and lowest during period I in Koraput district, i.e. 8.02\% per annum.

It is concluded from the result that the main source of growth in production of rice in Odisha is growth in yield during period II and period III. The growth for area, production and yield was negative during period I, but the instability was higher. The growth in area was negative during all the four periods and the growth in production is mainly due to growth in yield. During period II and III, the growth in area was negative, but instability was less while growth for production and yield was positive but the instability was higher. During the overall period IV, the growth in area was negative and low but instability was less, growth in production was positive and low but instability was higher and growth in yield was positive and higher as compared to growth of production but instability was higher but less than that of growth of production. The area was reducing day by day over the last few year so some steps are required to stop the decrease in area under rice cultivation in Odisha. Hence, the study will help the planner to plan the future rice production of the state.

\section{References}

Ayyasamy, P. K. and Subramanian, V. 1979. Growth rates in area, production and yield of rice in Tamil Nadu, Agricultural Situation in India, 33(12): 789-793.

Bera, B. K., A. J. Chakraborty, A. K. Nandi and Sarkar, A. 2011. Growth and Instability of Food-grain Production of India and West Bengal, Journal of Crop and Weed, 7(1): 94-100.

Cauvery, R. 1991. Groundnut Production in Tamil Nadu - A Decomposition Analysis, Agricultural Situation in India, 46(5): 321.

Cuddy, J. D. A. and Della, V. P. A. 1978. Measuring of Instability of Time Series Data, Oxford Bulletin of Economics and Statistics, 40(1): 79-85.

Deosthali, V. and Chandrahekhar, M. N. 2004. Rice: Region wise growth trends in Maharashtra, Economic and Political Weekly, 39(3): 240-242.

Minhas, B. S. 1966. Rapporteur's report on measurement of agricultural growth, Indian Journal of Agricultural Economics, 21(4): 165-182.

Prabhakaran, K. and Sivapragasam, C. 2013. Analysis of growth rates of rice and sorghum in Andhra Pradesh, International Journal of Farm Sciences, 3(1): 1-9.

Ranade, C. G. 1980. Impact of cropping pattern on agricultural production, Indian J. Agric. Econ., 35(2): 85-92.

Sen, S. 1967. Growth and instability in Indian Agriculture, Address to the twentieth conference of the Indian society of Agricultural Statistics, 10(12): 1-31.

Sikka, B. K. and Vaidya, C. S. 1985. Growth rates and cropping pattern changes in agriculture in Himachal Pradesh, Agricultural Situation in India, 39(11): 843-846.

Singh, D. V. and Swarup, R. 1988. Trends in Production, Productivity and Acreage of Pulses in Himachal Pradesh, Agriculture Situation in India, 43(4): 283-285.

Singh, D. V. 1981. A component analysis and value productivity growth of important crops in Himachal Pradesh, Agricultural Situation in India, 36(6): 479-484.

Singh, N., A. K. Dikshit, B. S. Reddy and Kuthe, S. B. 2014. Instability in rice production in Gujarat: A decomposition 
analysis, Asian Journal of Economics and Empirical Research, 1(1): 6-9.

Susella, K. and Chandrasekaran, M. 2016. Growth and Instability in Dryland Agriculture of Andhra Pradesh, International Journal of Agricultural Science and Research. 6(2): 285-294.

Swain, M. 2012. Sources of growth and instability in agricultural production in Western Odisha, India, Asian Journal of Agriculture and Development, 11(2): 51-70.
Tewari, H., H. P. Singh and Tripathi, U. 2017. Growth and instability in wheat production: A region wise analysis of Uttar Pradesh, India, International Journal of Current Microbiology and Applied Sciences, 6(9): 2537-2544.

Tripathy, S. and Srinivasagowda, M. 1995. An analysis of growth instability and area response of groundnut in Orissa, Indian Journal of Agricultural Economics, 48(3): 345-350.

\section{How to cite this article:}

Nitiprasad Namdeorao Jambhulkar, Sushree Sangeeta Jena, Biswajit Mondal and Parshuram Samal. 2020. Estimation of Growth Rate and Instability Analysis of Area, Production and Yield of Rice in Odisha State of India. Int.J.Curr.Microbiol.App.Sci. 9(07): 3107-3115. doi: https://doi.org/10.20546/ijcmas.2020.907.366 